\title{
Study on UV Absorption Materials Derived from Red Algae Gloiopeltis fucatas and Mazzaella sp. in Russia
}

\author{
Moon-Hee Lee ${ }^{1}$, Yeon-Kye Kim ${ }^{2}$, Na Young Yoon ${ }^{1}$, Kil Bo Shim ${ }^{1}$, Natalya M. Aminina ${ }^{3}$, Irina A. Kadnikova \\ and Chi-Won Lim ${ }^{1 *}$ \\ ${ }^{1}$ Food and Safety Research Division, National Fisheries Research and Development Institute, Busan 619-705, Korea \\ ${ }^{2}$ Southwest Sea Fisheries Research Institute, National Fisheries Research and Development Institute, Yeosu 556-823, Korea \\ ${ }^{3}$ Algae Rational Utilization, TINRO-center, Vladivostok 690091, Russia
}

\begin{abstract}
We investigated ultraviolet (UV) absorption materials from Russian seaweeds. First, the UV absorptivities of five seaweeds Gloiopeltis fucatas, Mazzaella sp., Mastocarpus pacificus, Laminaria cichorioides, Saccharina japonica were evaluated by a UV spectrometer. Of these seaweeds, Gloiopeltis fucatas and Mazzaella sp. showed high levels of UV absorption. Column chromatography of active 50\% aqueous ethanol extracts from Gloiopeltis fucatas and Mazzaella sp. resulted in the purification of two known compounds. Spectroscopic techniques identified their structures as shinorine and palythine. These materials exhibited UV absorptive capabilities at wavelengths of 333 and $320 \mathrm{~nm}$, respectively. These results suggest that Gloiopeltis fucatas and Mazzaella sp. may be useful as natural cosmeceutical sources.
\end{abstract}

Key words: Gloiopeltis fucatas., Mazzaella sp., Russian seaweeds, Shinorine, Palythine

\section{Introduction}

Gloiopeltis fucatas red algae belonging to the family Endocladiaceae, have been traditionally consumed as medicines and food thickeners in China and Japan (Schachat and Glicksman, 1959). Various beneficial effects have been reported, such as anti-inflammatory and anti-tumor activities (Niu et al., 2003; Bae and Choi, 2007). Mazzaella sp. belong to the family Gigartinaceae and are distributed in the north and west Pacific, around Pacific South America, Gough Island and off South Africa (Hommersand et al., 1993). They are well known as sources of carrageenan which is used as a food additive.

Ultraviolet (UV) radiation is one of the most harmful exogenous agents and affects numerous biological functions in all sun-exposed living organisms. Organisms are exposed to solar radiation, including harmful UV-B $(280-320 \mathrm{~nm})$ and UV-A (315-400 nm) radiation, in their natural habitats. Repetitive exposure to sun causes premature skin aging (Marrot and Meunier, 2008) and skin cancer (Afaq et al., 2005; de Gruijl and Ananthaswamy, 2010). In response to intense solar radiation, organisms have evolved certain mechanisms, such as avoidance, repair, and protection by synthesizing or accumulating photoprotective compounds, such as mycosporinelike amino acids (MAAs).

In the present study, we investigated the UV absorption power of Russian seaweeds and isolated UV-absorbing constituents from them.
Open Access http://dx.doi.org/10.5657/FAS.2012.0361

This is an Open Access article distributed under the terms of the Creative Commons Attribution Non-Commercial License (http://creativecommons, org/licenses/by-nc/3.0/) which permits unrestricted non-commercial use, distribution, and reproduction in any medium, provided the original work is properly cited. pISSN: 2234-1749 eISSN: 2234-1757
Received 18 October 2012; $\quad$ Revised 8 November 2012 Accepted 12 November 2012

*Corresponding Author

E-mail: whasoo@korea.kr 


\section{Materials and Methods}

\section{Samples}

Five species of seaweed were collected at Sacchalin, Russia, from February to July 2011 (Table 1) by the TINRO-center, and stored frozen at $-20^{\circ} \mathrm{C}$.

\section{Extraction}

The seaweeds samples were extracted in 10 volumes of $0 \%$, $50 \%$, and $100 \%$ aqueous ethanol a using sonicator. The extracts were evaporated using a rotary evaporator.

\section{Isolates derived from Gloiopeltis fucatas and Mazzaella sp. in Russia}

The 50\% aqueous ethanol extracts from Gloiopeltis fucatas $(0.5 \mathrm{~g})$ and Mazzaella sp. (0.5 g) were subjected to column chromatography over silica gel (silica gel 60, 0.063-0.200 mm; Merck, Darmstadt, Gerrmany) and eluted with $80 \%$ aqueous acetonitrile, to yield four subfractions (G 1-4) and five subfractions (M 1-3) based on thin layer chromatography analysis, respectively. Then, separations of fractions G 3 (0.35 g) and M 4 (0.35 g) were carried out on a Dionxe P690 HPLC system equipped with a UV detector (Dionex UVD 170U; Thermo Scientific, San Jose, CA, USA). High-performance liquid chromatography conditions were as follows: guard column, C18 (i.d. $4.6 \times 7.5 \mathrm{~mm}, 5 \mathrm{U}$; Alltech, Woodridge, IL, USA ); column, Intersil ODS-3V (i.d. $4.6 \times 150 \mathrm{~mm}, 5 \mu \mathrm{m}$; GL Science Inc., Tokyo, Japan); flow rate, $0.7 \mathrm{~mL} / \mathrm{min}$; detection wavelengths, 320 and $333 \mathrm{~nm}$. An eluent solvent was followed by $50 \%$ acetonitrile (in $0.2 \%$ acetic acid) within 30 min. The structures were analyzed from spectral data using nuclear magnetic resonance and electrospray ionization mass spectrometry.

\section{Measurements of UV absorption spectra}

UV absorption spectra of seaweed extracts were evaluated using an Optizen 2120UV spectrophotometer (Mecasys, Daejeon, Korea) for wavelengths of 240 to $720 \mathrm{~nm}$ at a concentration of $1 \mathrm{mg} / \mathrm{mL}$ (Oyamada et al., 2008).

Table 1. The yield of five Russian seaweeds (\%)

\begin{tabular}{llc}
\hline Phylum & \multicolumn{1}{c}{ Classification } & Yield (\%) $^{*}$ \\
\hline Phodophyta & Gloiopeltis fucatas & 10.32 \\
& Mazzaella sp. & 11.77 \\
& Mastocarpus pacificus & 8.23 \\
Phaeophyta & Laminaria cichorioides & 5.23 \\
& Saccharina japonica & 7.35 \\
\hline
\end{tabular}

"The yield was expressed as percentage and calculated with the 50\% aqueous ethanol extract weight per dry sample weight.

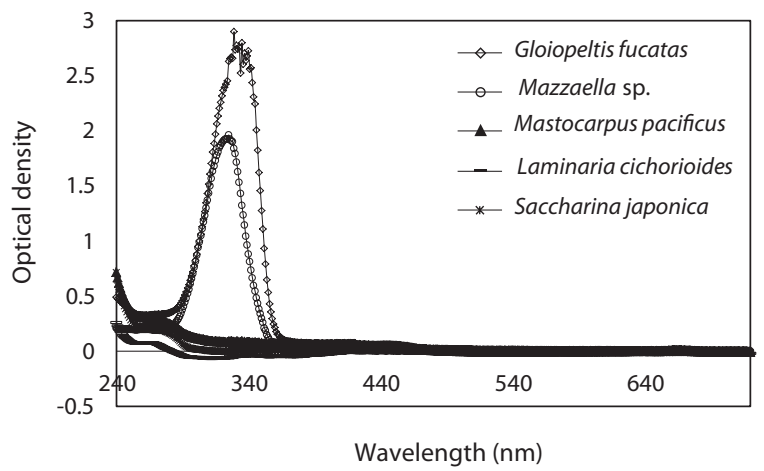

Fig. 1. Ultraviolet spectrum on $50 \%$ aqueous ethanol extracts of the five seaweeds from Russia.
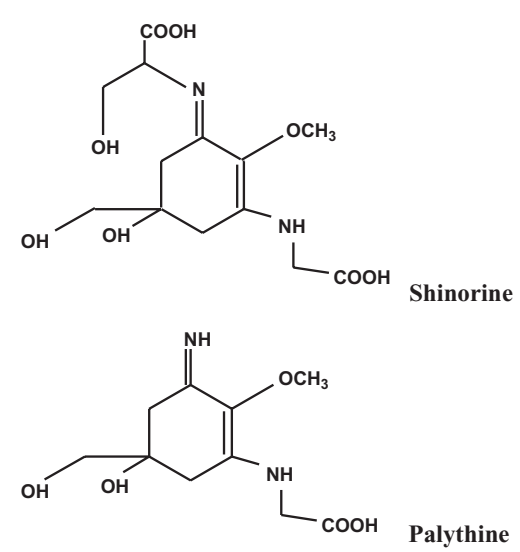

Fig. 2. Structures of compounds 1 and 2 isolated from Gloiopeltis fucatas and Mazzaella sp., respectively.

\section{Results and Discussion}

UV radiation is either reflected or absorbed by sunscreens. Different structural molecules have unique absorption wavelengths. An absorption spectrum will show a number of absorption bands that correspond to structural groups within the molecules.

In the present study, we examined the UV absorption properties of five Russian seaweeds within the range of 240 to $720 \mathrm{~nm}$. Among the seaweeds, Gloiopeltis fucatas and Mazzaella sp. had the highest absorption peaks between 280 and $360 \mathrm{~nm}$, while the other species did not show any absorption peaks (Fig. 1). We also measured the UV absorption activities of $0 \%, 50 \%$ and $100 \%$ aqueous ethanol extracts of Gloiopeltis fucatas and Mazzaella sp. to identify active UV-aborbing materials. Among these, 50\% aqueous ethanol extracts from Gloiopeltis fucatas and Mazzaella sp. had high absorption peaks between 280 and $360 \mathrm{~nm}$. These extracts were purified via column chromatography and two compounds were isolated. Their structures were identified as shinorine and palythine through comparisons with spectral data and the literature 


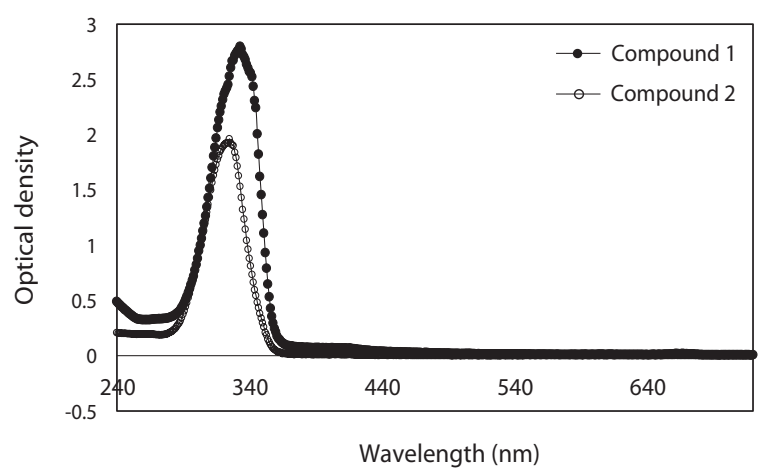

Fig. 3. Ultraviolet spectrum of the compound 1 and 2 isolated from Gloiopeltis fucatas and Mazzaella sp.

(Fig. 2) (Bandaranayake, 1998; Shick and Dunlap, 2002; Oyamada et al., 2008). This is the first time that these compounds have been isolated from Gloiopeltis fucatas and Mazzaella sp. Compound 1 and 2 showed maximum UV absorption peaks at 333 and $320 \mathrm{~nm}$, respectively (Fig. 3).

Shinorine and palythine are MAAs. MAAs are colorless water-soluble secondary metabolites that have a cyclohexenone chromophore conjugated to a nitrogen substituent of either an amino acid or imino alcohol; they have been identified in fungal metabolites, cyanobacteria, red algae, and corals (Takano et al., 1978; Dunlap and Yamamoto, 1995; Bandaranayake, 1998; Shick and Dunlap, 2002). MAAs have high levels of absorption for UV-A and UV-B (280-400 nm) (Bandaranayake, 1998; Shick and Dunlap, 2002).

In conclusion, extracts from Gloiopeltis fucatas and Mazzaella sp. and MAAs derived from the extracts had strong UV absorption effects. Further study is needed to isolate and purify additional UV absorption materials from Gloiopeltis fucatas and Mazzaella sp. extracts.

\section{Acknowledgments}

This research was funded by a grant from the National Fisheries Research and Development Institute, Korea (RP-2012FS-031).

\section{References}

Afaq F, Adhami VM and Mukhtar H. 2005. Photochemoprevention of ultraviolet B signaling and photocarcinogenesis. Mut Res 571, 153-173.

Bae SJ and Choi YH. 2007. Methanol extract of the seaweed Gloiopeltis furcata induces $\mathrm{G} 2 / \mathrm{M}$ arrest and inhibits cyclooxygenase-2 activity in human hepatocarcinoma HepG2 cells. Phytother Res 21, 52-57.

Bandaranayake WM. 1998. Mycosporines: are they nature's sunscreens? Nat Prod Rep 15, 159-172.

de Gruijl FR and Ananthaswamy HN. 2010. Ultraviolet radiation as a carcinogen. In: Comprehensive Toxicology. McQueen CA, ed. Elsevier, Oxford, US, pp. 161-179.

Dunlap WC and Yamamoto Y. 1995. Small-molecule antioxidants in marine organisms: antioxidant activity of mycosporine-glycine. Comp Biochem Physiol B Biochem Mol Biol 112, 105-114.

Hommersand MH, Guiry MD, Fredericq S and Leister GL. 1993. New perspectives in the taxonomy of the Gigartinaceae (Gigartinales, Rhodophyta). Hydrobiologia 260/261, 105-120.

Marrot L and Meunier JR. 2008. Skin DNA photodamage and its biolobical consequences. J Am Acad Dermatol 58(5 Suppl 2), S139S148.

Niu R, Fan X and Han L. 2003. A screening for the anti-inflammatory effect of algal extracts. Oceanol Limnol Sin 34, 150-154.

Oyamada C, Kaneiwa M, Ebitani K, Murata M and Ishihara K. 2008. Mycosporine-like amino acids extracted from scallop (Patinopecten yessoensis) ovaries: UV protection and growth stimulation activities on human cells. Mar Biotechnol 10, 141-150.

Schachat RE and Glicksman M. 1959. Some lesser known seaweed extracts. In: Industrial Gums. Whistler RL, ed. Academic Press, New York, US, pp. 135-191.

Shick JM and Dunlap WC. 2002. Mycosporine-like amino acids and related gadusols: biosynthesis, accumulation, and UV-protective functions in aquatic organisms. Annu Rev Physiol 64, 223-262.

Takano S, Uemura D and Hirata Y. 1978. Isolation and structure of two new amino acids, palythinol and palythene, from the zoanthid $\mathrm{Pa}$ lythoa tuberculosa. Terahedron Lett 49, 4909-4912. 